\title{
Simulation strength tests of a CLAAS ARION 610 rail-road tractor's load-bearing structure (pt. 2)
}

\author{
Symulacyjne badania wytrzymałości struktury nośnej \\ dwudrogowego ciągnika CLAAS ARION 610 (cz. 2)
}

\begin{abstract}
In the first part of the article published in Rail Vehicles No. 2/2020, selected results of simulation tests of the strength of the front part of the supporting structure of the CLAAS ARION 610 tractor were presented. That part was mostly focused on the strength analysis of the front axle bracket, which is the basic factory supporting element of the front part of the tractor.

The second part of the article presents the results of strength tests of the tractor's rear support structure, where all the elementary components of the additional tractor equipment were made in the Eukasiewicz Research Network - IPS "TABOR", load-bearing frame, a buffer beam and a drawbar. The buffer beam and the drawbar are also accessories of the front supporting structure and they are subjected to the same load conditions with horizontal forces as in the rear pull-buffer system.

The first part of the article was published in the previous issue of the Rail Vehicles quarterly journal.

W pierwszej części artykułu opublikowanego w Pojazdach Szynowych nr 2/2020 zaprezentowano wybrane wyniki badań symulacyjnych wytrzymatości przedniej części struktury nośnej ciqgnika CLAAS ARION 610. Najwięcej uwagi poświęcono analizie wytrzymałości wspornika przedniej osi, który jest podstawowym fabrycznym elementem nośnym przedniej części ciagnika. $W$ drugiej części artykułu przedstawiono wyniki badań wytrzymatości tylnej struktury nośnej ciagnika, gdzie wszystkie części sktadowe stanowiq dodatkowe wyposażenie ciagnika wykonane w Sieci Badawczej Łukasiewicz - IPS „TABOR”, złożone ze skrzyni nośnej, belki zderzakowej oraz haka pociagowego. Belka zderzakowa oraz hak pociagowy stanowiq również wyposażenie przedniej struktury nośnej i sq one poddane tym samym warunkom obciqżeń siłami poziomymi jak w tylnym uktadzie pociagowo-zderznym.

Część pierwsza artykułu została opublikowana w poprzednim numerze kwartalnika Pojazdy Szynowe.
\end{abstract}

\section{Rear pull-buffer system}

The tested structure model of the rear pull-buffer system was shown in Figure 2 in the first part of the article. The study presents the results of strength analyzes of the components in the rear pull-buffer system.

\section{Model of the load-bearing frame structure}

The basic load-bearing structure of the rear pull-buffer system is the box frame structure item $\mathbf{1}$ in Fig. 8.1, to which mounting plates 2 for the installation of the buffer beam or SA3 automatic coupler were welded, along with brackets $\mathbf{3}$ for mounting hydraulic cylinders of the rail undercarriage frame, brackets $\mathbf{4}$ for mounting the rocker arms of the rail track connecting wheels, brackets $\mathbf{5}$ for transverse stabilization of the axis of the rail wheels on the track and brackets $\mathbf{6}$ for compressor installation.

\section{Tylny układ pociągowo-zderzny}

Model badanej struktury tylnego układu pociagowozderznego przedstawiono na rys. $2 \mathrm{w}$ pierwszej części artykułu. W opracowaniu zaprezentowano wyniki analiz wytrzymałości części składowych tylnego układu pociagowo-zderznego.

\section{Model struktury nośnej konstrukcji skrzynkowej}

Podstawową strukturę nośną tylnego układu pociagowo-zderznego stanowi konstrukcja skrzyniowa poz.1 (rys. 8.1), do której dospawano płyty mocujące 2 do zabudowy belki zderzakowej lub sprzęgu samoczynnego SA3, wsporników 3 do mocowania siłowników hydraulicznych szynowego układu jezdnego, wsporników 4 mocowania wahaczy szynowego układu jezdnego, wsporników 5 poprzecznego prowadzenia osi 
Rear structure compression - $300 \mathbf{k N}$ : exerted forces and research results

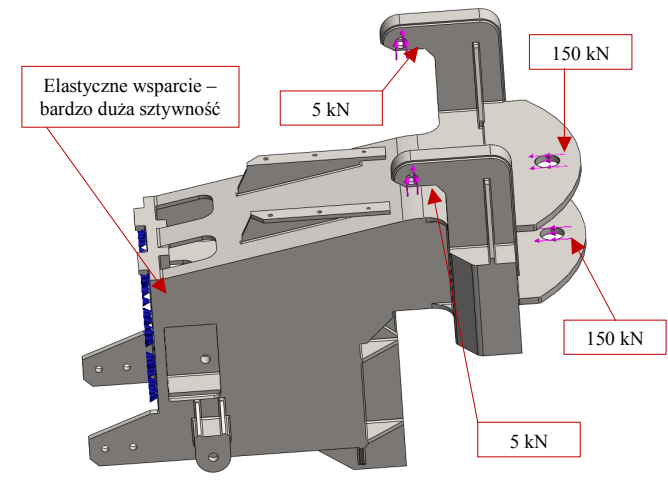

Fig. 8.2. Mounting and forces

Rys. 8.2. Obciążenia i umocowanie

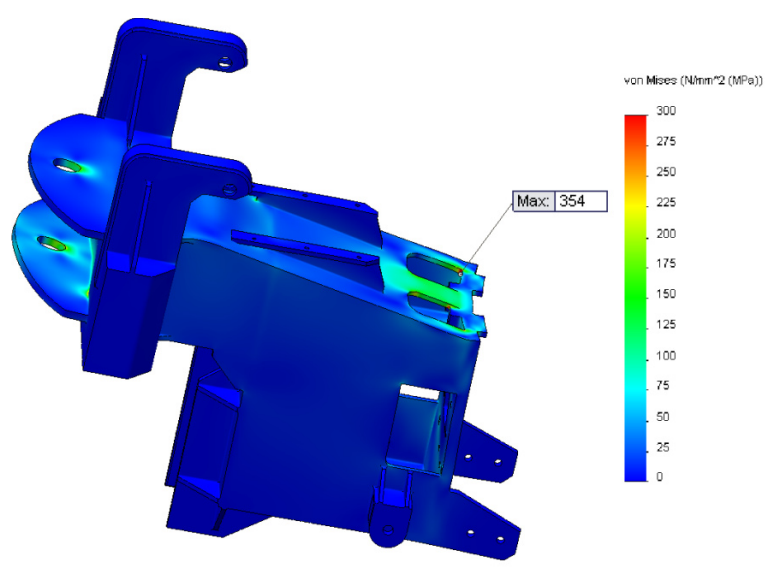

Fig. 8.3.Distribution of reduced tension Rys. 8.3. Rozkład naprężeń zredukowanych

Rear structure stretching force $-150 \mathrm{kN}$ : exerted forces and research results

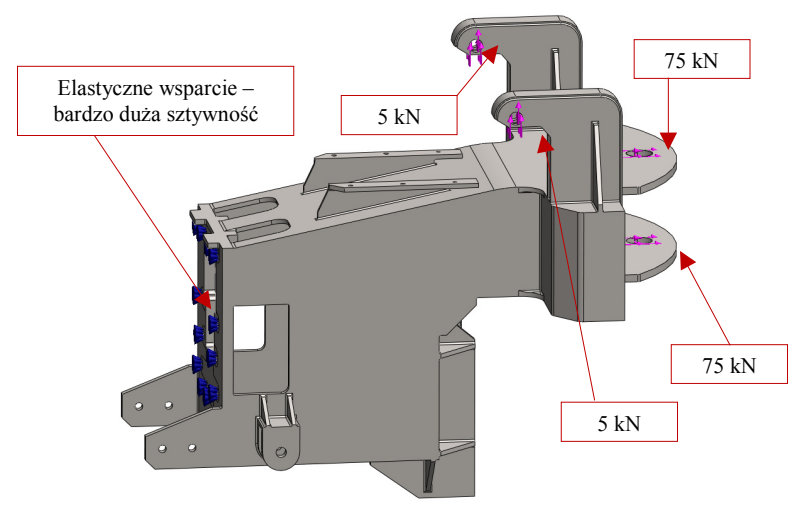

Fig. 8.5. Mounting and forces

Rys. 8.5. Obciążenia i umocowanie szynowego układu jezdnego oraz wsporników 6 do zabudowy sprężarki.

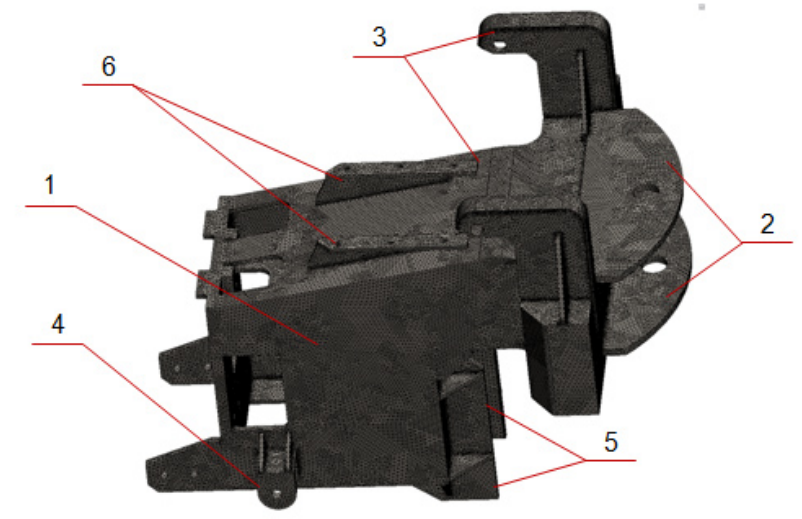

Fig. 8.1. Supporting structure of the rear pull-buffer system Rys. 8.1. Konstrukcja nośna tylnego układu pociagowo-zderznego

\section{Ściskanie tylnego układu - 300 kN: obciążenia i wyniki badań}

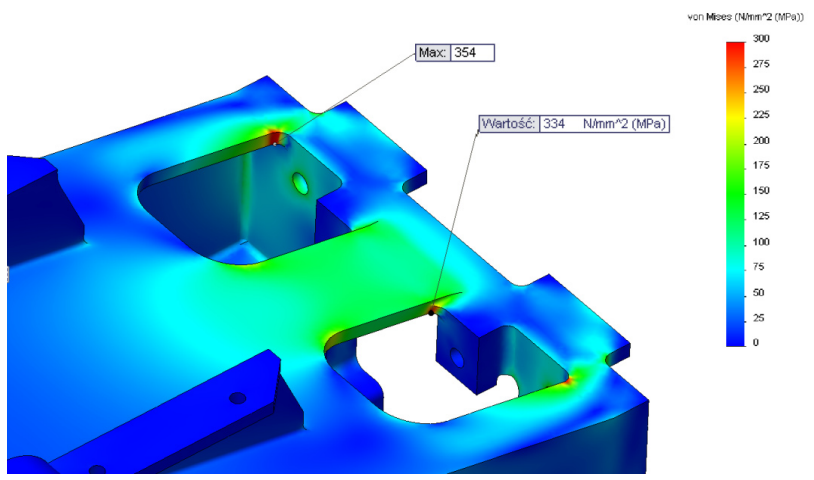

Fig. 8.4. Distribution of reduced tension Rys. 8.4. Rozkład naprężeń zredukowanych

Rozciąganie tylnego ukladu - 150 kN: obciążenia i wyniki badań

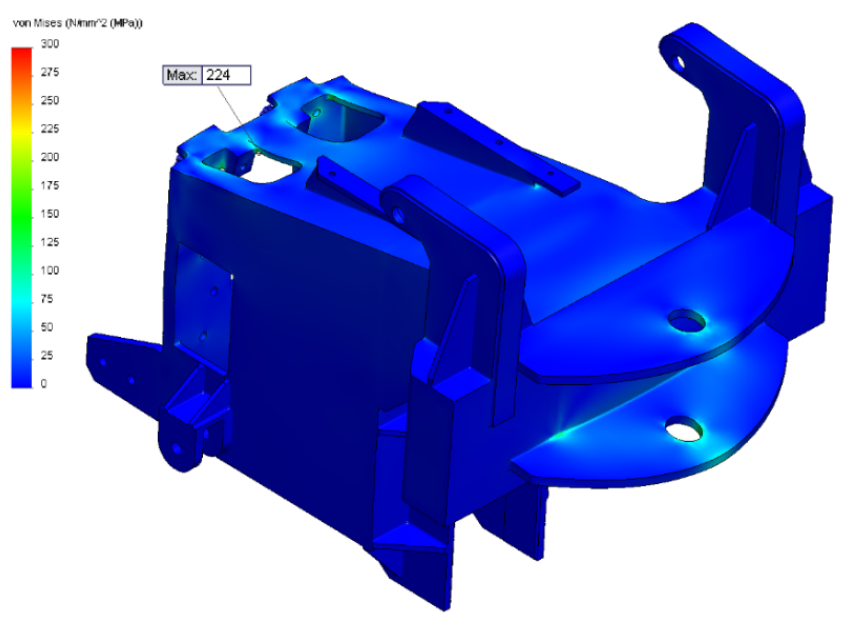

Fig. 8.6. Distribution of reduced tension Rys. 8.6. Rozkład naprężeń zredukowanych

Rear structure vertical forces $-60 \mathrm{kN}$ : exerted forces and research results

Obciążenia pionowe tylnego układu - $60 \mathrm{kN}$ : obciążenia i wyniki badań 


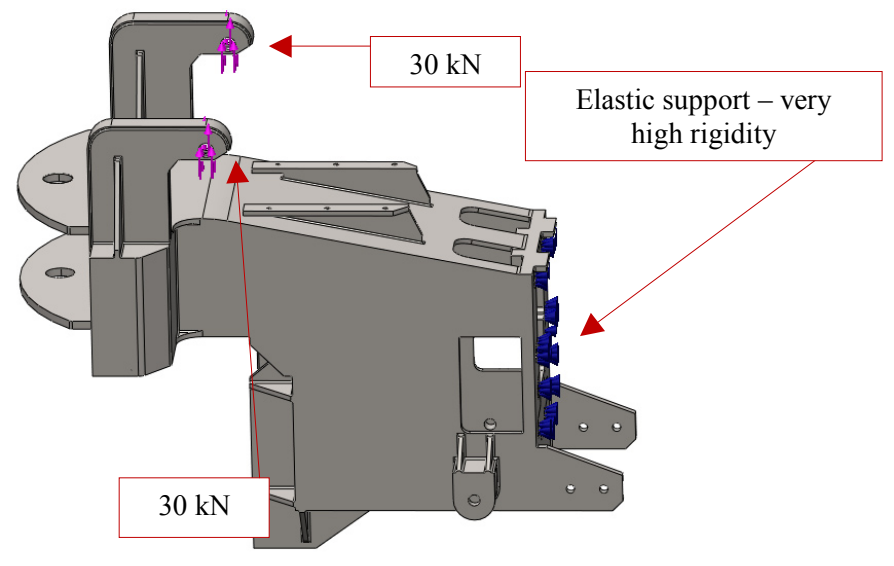

Fig. 8.7. Mounting and forces

Rys. 8.7. Obciążenia i umocowanie

\section{The buffer beam model}

Beam compression $-300 \mathrm{kN}$ : exerted forces and research results

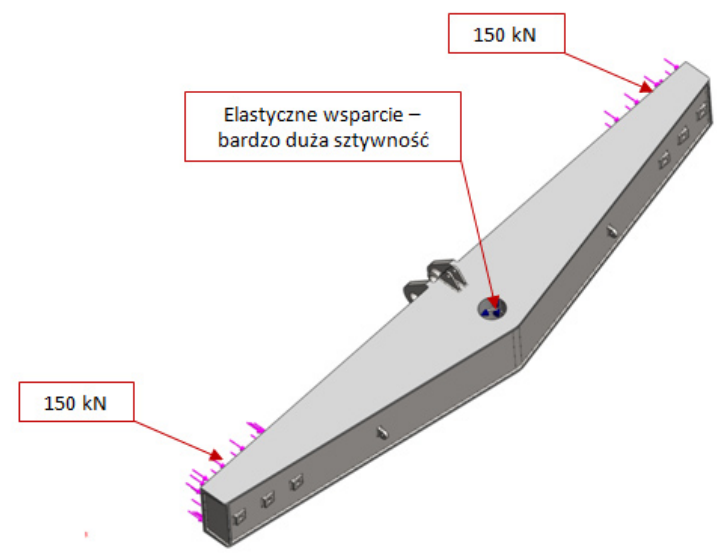

Fig. 9.1. Mounting and forces

Rys. 9.1. Obciążenia i umocowania

Beam stretching $-150 \mathrm{kN}$ : exerted forces and research results

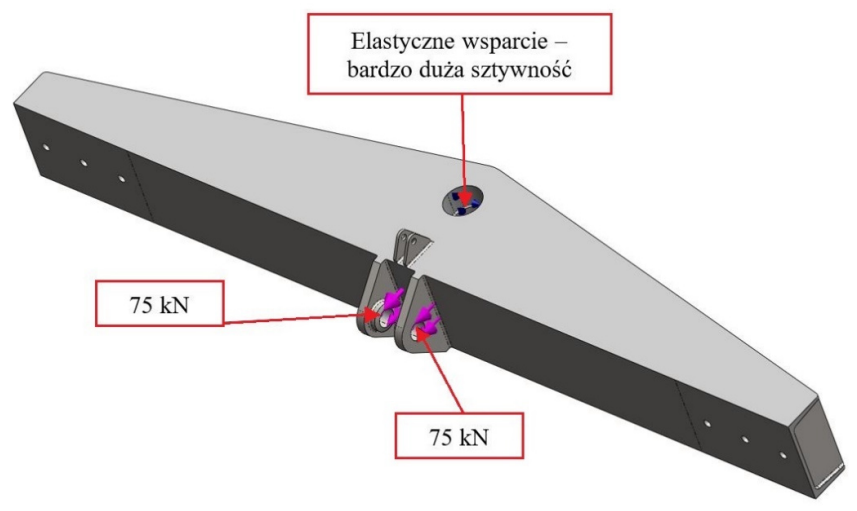

Fig. 9.3. Mounting and forces (Elastyczne wsparcie - bardzo duża sztywność: - Elastic support - very high rigidity)

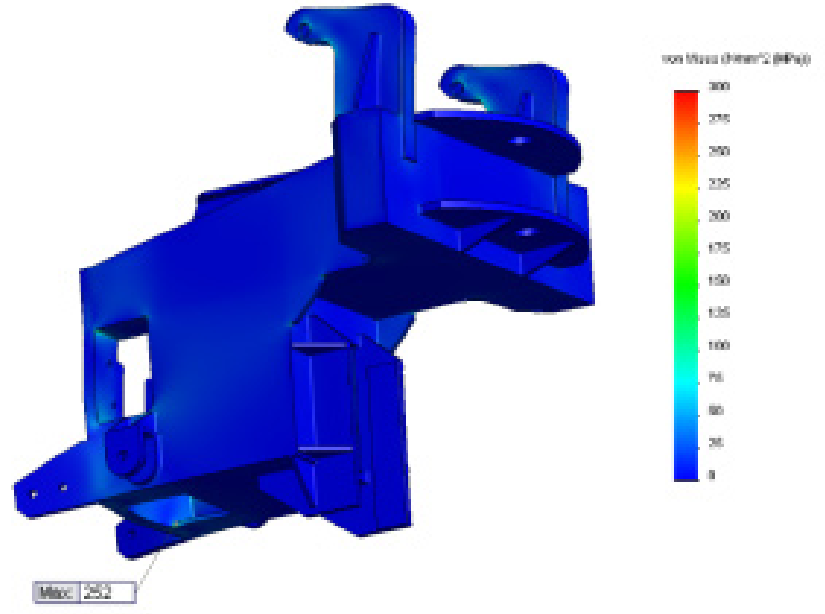

Fig. 8.8. Distribution of reduced tension

Rys. 8.8. Rozkład naprężeń zredukowanych

\section{Model belki zderzakowej}

Ściskanie belki - 300 kN: obciążenia i wyniki badań

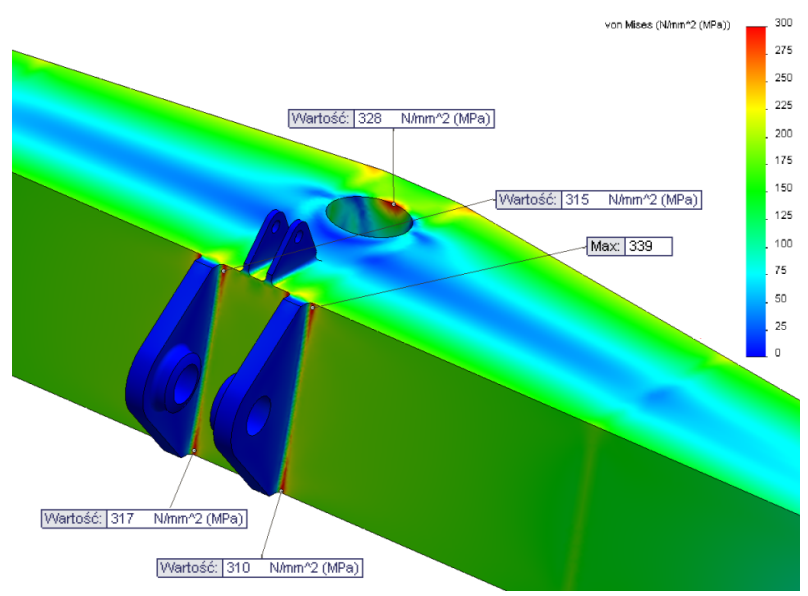

Fig. 9.2. Distribution of reduced tension

Rys. 9.2. Rozkład naprężeń zredukowanych

\section{Rozciąganie belki - 150kN: obciążenia i wyniki} badań

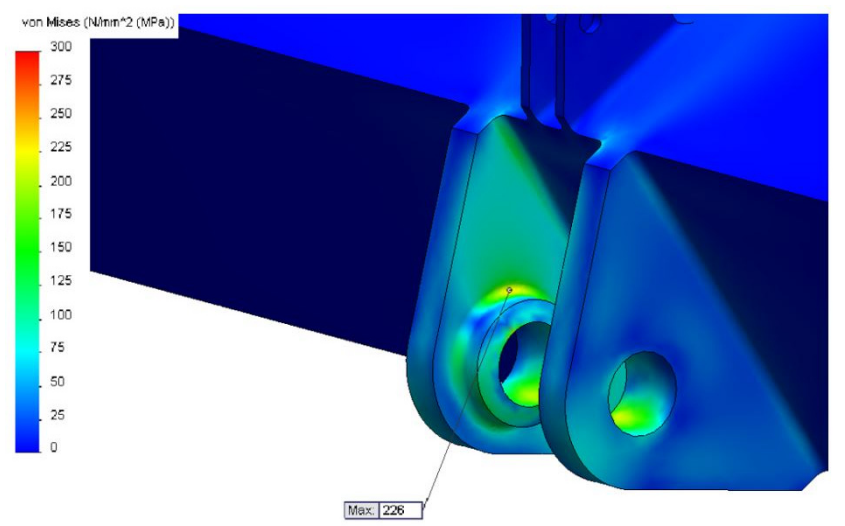

Fig. 9.4. Distribution of reduced tension Rys. 9.4. Rozkład naprężeń zredukowanych 
10. Pull hook model

Stretching with the force of $150 \mathrm{kN}$

The model was comprised of the following elements:

- beam with supporting lugs and a pin $-\mathbf{1}$

- coupling bolt -2

- lock with a bolt $-\mathbf{3}$

- hook -4 .

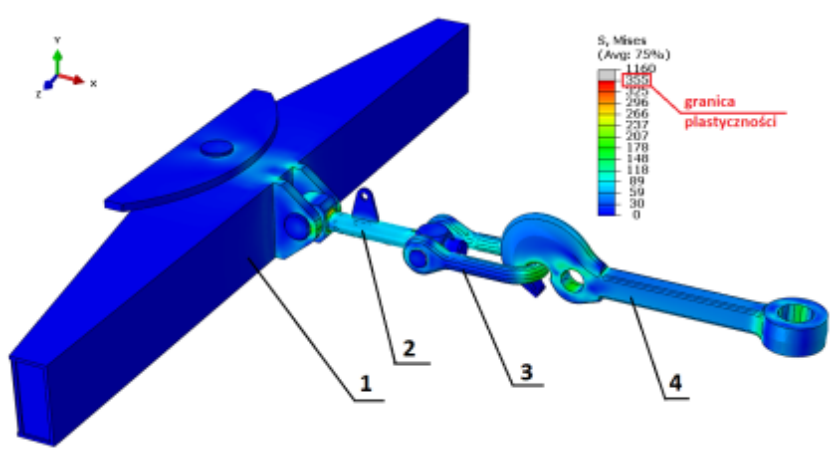

Fig. 10.1. Tested model (granica plastyczności - yield strength) Rys. 10.1. Badany model

\section{Research results}

The test results were shown in Fig. 10.3.
10. Model haka pociągowego

Rozciąganie silą $150 \mathrm{kN}$

Model złożono z następujących elementów:

- belka z uszami wsporczymi i sworzniem - 1

- śruba sprzęgu - 2

- pałąk z nakrętką $-\mathbf{3}$

- hak - 4

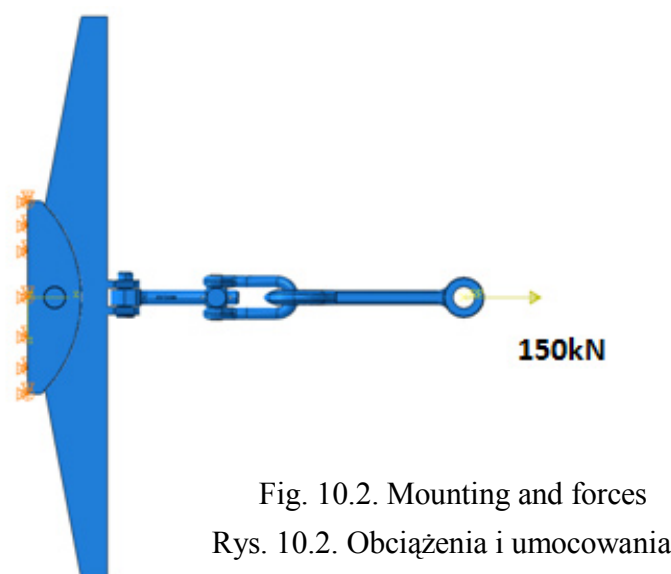

Wyniki badań

Wyniki badań przedstawiono na rys. 10.3.

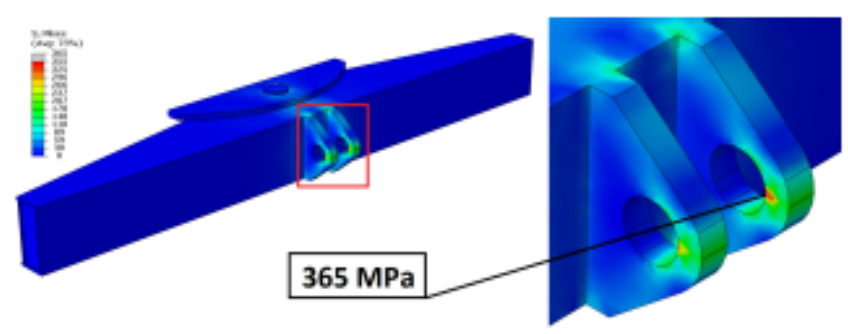

Fig. 10.3. Distribution of reduced tension

Rys. 10.3. Rozkład naprężeń zredukowanych
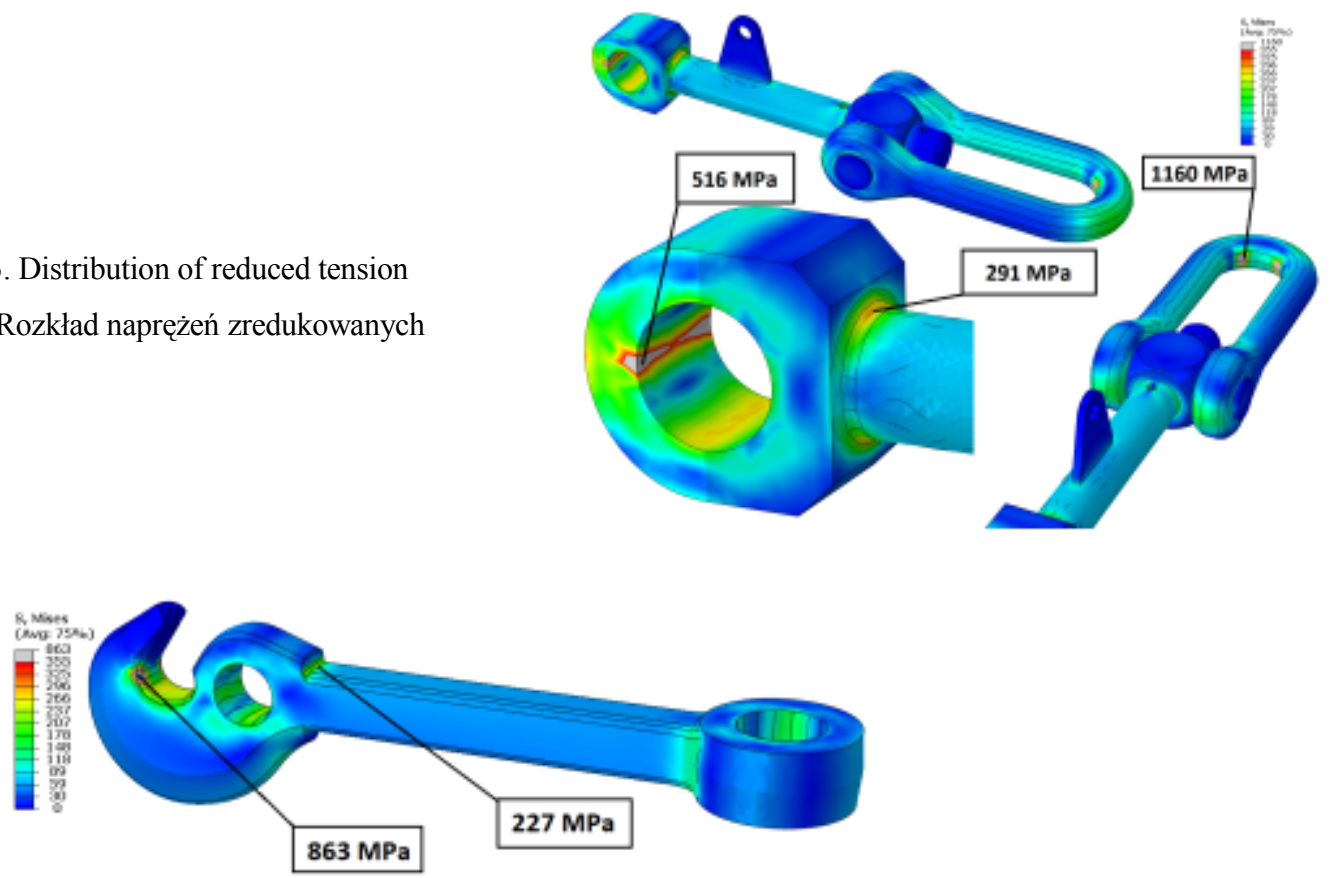


\section{Estimating the tractor maximum safe buffer contact speed}

Calculations of the maximum speed of the tractor runin when connecting with the wagon were made with the following assumptions:

- tractor mass was assumed as $10000 \mathrm{~kg}$

- the tractor runs into contact with a stationary wagon with enabled brakes (the wagon does not move when the tractor buffers hit it)

- the wagon is equipped with category $\mathrm{C}$ buffers

- the maximum impact run-in force of the buffers on the tractor during the contact was $300 \mathrm{kN}$ ( $150 \mathrm{kN}$ on each buffer).

The norms [2] specify the requirements that are to be met by a category $\mathrm{C}$ buffer, but these requirements are quite general, therefore, for the calculations, the characteristics of a specific bumper was used, Fig. 11.1.

\section{Oszacowanie maksymalnej prędkości nabiega- nia ciągnika}

Obliczenia maksymalnej prędkości nabiegania ciągnika na wagon zostały wykonane przy następujących założeniach:

- masa ciągnika wynosi $10.000 \mathrm{~kg}$

- ciągnik najeżdża na nieruchomy, zahamowany wagon (podczas najazdu nie następuje przesuniecie wagonu)

- wagon wyposażony jest w zderzaki kategorii C

- maksymalna siła oddziaływania zderzaków na ciagnik podczas najazdu wynosi $300 \mathrm{kN}$ (po 150 $\mathrm{kN}$ na zderzak).

Norma [2] określa wymagania jakie powinien spełniać zderzak kategorii $\mathrm{C}$, wymagania te są jednak dosyć ogólne, dlatego na potrzeby obliczeń zdecydowano się wykorzystać charakterystykę konkretnego zderzaka rys. 11.1 .

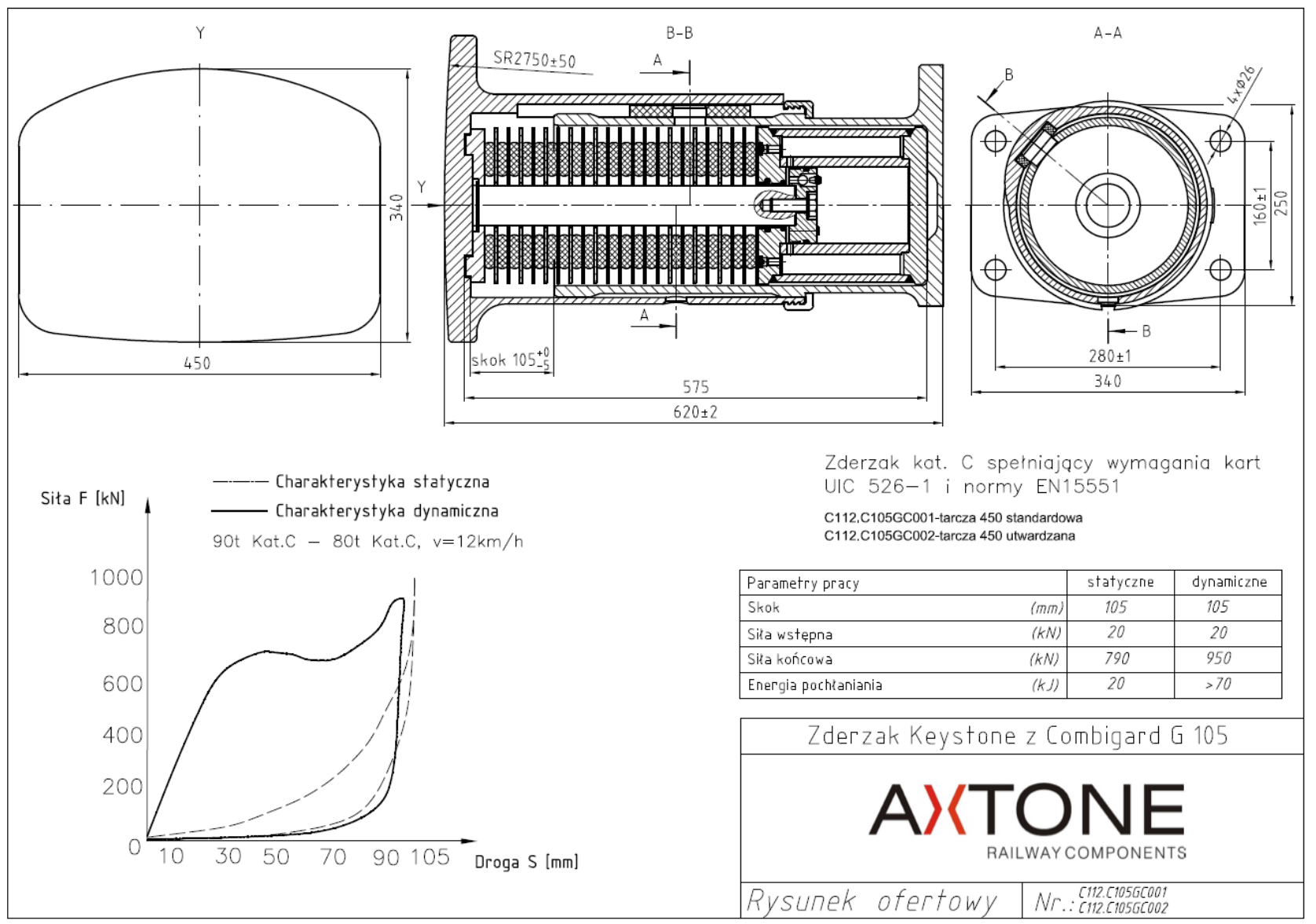

Rys. 11.1. Karta katalogowa zderzaka przyjętego do obliczeń

Fig. 11.1. Data sheet of the buffer used for calculations (Zderzak Keystone z - Keystone buffer with, charakterystyka statyczna/dynamiczna - static/dynamic characteristics, Zderzak kat. C spełniający wymagania kart ... i normy - category C buffer meeting the requirements of card ... and norm ..., Parametry pracy - parameters, statyczne/dynamiczne - static/dynamic, Skok - compression, Siła wstępna - initial force, Siła końcowa - final force, Energia pochłaniania - energy dissipation) 
For the static characteristic, the compression as a result of the force of $150 \mathrm{kN}$ was $\mathrm{d}_{\mathrm{zs}} \approx 55 \mathrm{~mm}$, and for the dynamic characteristic, it was $d_{z s} \approx 7 \mathrm{~mm}$. Assuming a linear force increase due to deformation in the analyzed range of displacements, the energy absorbed by one buffer was:

$$
\begin{aligned}
& E_{p z s}=\frac{1}{2} \cdot F \cdot d_{z s}=\frac{1}{2} \cdot 150 \cdot 55[\mathrm{kN} \cdot \mathrm{mm}]=4125[\mathrm{~J}] \\
& E_{p z d}=\frac{1}{2} \cdot F \cdot d_{z s}=\frac{1}{2} \cdot 150 \cdot 7[\mathrm{kN} \cdot \mathrm{mm}]=525[\mathrm{~J}]
\end{aligned}
$$

where:

$E_{p z s}-$ energy absorbed by one buffer, determined on the basis of the static characteristic,

$E_{p z d^{-}}$energy absorbed by one buffer, determined on the basis of the dynamic characteristic.

The compression of one rubber damper installed on the tractor's buffer beam (consisting of three rubber plates made of rubber with a hardness of $80 \mathrm{ShA}$ ) under the force of $150 \mathrm{kN}$ was $d_{\mathrm{a}} \approx 20 \mathrm{~mm}$ Fig. 11.2, hence the energy absorbed by this element was:

$$
E_{p a}=\frac{1}{2} \cdot F \cdot d_{z s}=\frac{1}{2} \cdot 150 \cdot 20[\mathrm{kN} \cdot \mathrm{mm}]=1500[\mathrm{~J}]
$$

where:

$E_{p a}$ - energy absorbed by one rubber damper.

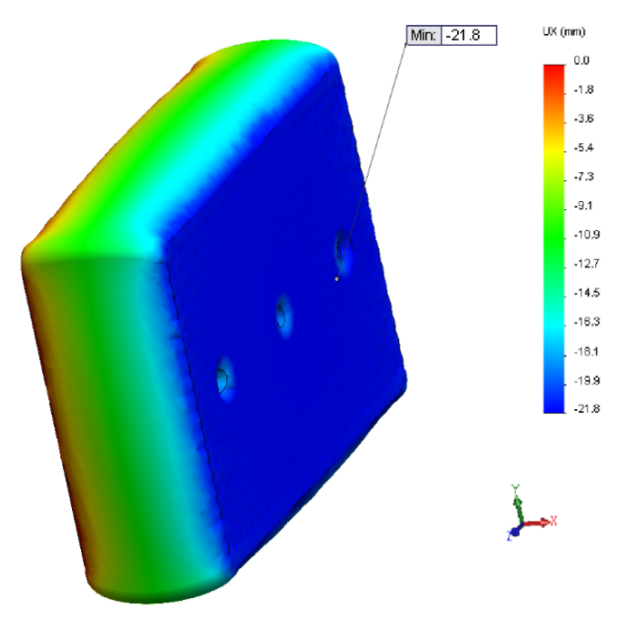

Fig. 11.2. Compression of the rubber shock absorber as a result of a compressive force of $150 \mathrm{kN}$

Rys. 11.2. Ugięcie amortyzatora gumowego pod wpływem siły ściskającej $150 \mathrm{kN}$

The total energy absorbed by the system of two buffers and two rubber shock absorbers was:

$$
\begin{aligned}
& E_{p s}=2 E_{p z s}+2 E_{p a}=2 \cdot 4125+2 \cdot 1500[\mathrm{~J}]=11250[\mathrm{~J}] \\
& E_{p d}=2 E_{p z d}+2 E_{p a}=2 \cdot 525+2 \cdot 1500[\mathrm{~J}]=4050[\mathrm{~J}]
\end{aligned}
$$

where:

$E_{p s}$ - energy absorbed by the system determined on the basis of the static characteristics

$E_{p d}$ - energy absorbed by the system determined on the basis of the dynamic characteristics
Dla charakterystyki statycznej ugięcie pod wpływem siły $150 \mathrm{kN}$ wynosi $\mathrm{d}_{\mathrm{zs}} \approx 55 \mathrm{~mm}$, a dla charakterystyki dynamicznej $\mathrm{d}_{\mathrm{zs}} \approx 7 \mathrm{~mm}$. Zakładając liniowy przyrost siły od odkształcenia w analizowanym zakresie przemieszczeń energia pochłonięta przez jeden zderzak wyno-

si:

$$
\begin{gathered}
E_{p z s}=\frac{1}{2} \cdot F \cdot d_{z s}=\frac{1}{2} \cdot 150 \cdot 55[\mathrm{kN} \cdot \mathrm{mm}]=4125[\mathrm{~J}] \\
E_{p z d}=\frac{1}{2} \cdot F \cdot d_{z s}=\frac{1}{2} \cdot 150 \cdot 7[\mathrm{kN} \cdot \mathrm{mm}]=525[\mathrm{~J}]
\end{gathered}
$$

gdzie:

$E_{p z s}$ - energia pochtonięta przez jeden zderzak wyznaczona na podstawie charakterystyki statycznej, $E_{p z d}$ - energia pochtonięta przez jeden zderzak wyznaczona na podstawie charakterystyki dynamicznej.

Ugięcie jednego amortyzatora gumowego zainstalowanego na belce zderzakowej ciagnika (składającego się $\mathrm{z}$ trzech płyt gumowych wykonanych $\mathrm{z}$ gumy o twardości $80 \mathrm{ShA}$ ) pod wpływem siły $150 \mathrm{kN}$ wynosi $d_{a} \approx 20 \mathrm{~mm}$ (rys. 11.2), stąd energia pochłonięta przez ten element:

$$
E_{p a}=\frac{1}{2} \cdot F \cdot d_{z s}=\frac{1}{2} \cdot 150 \cdot 20[\mathrm{kN} \cdot \mathrm{mm}]=1500[\mathrm{~J}]
$$

gdzie:

$E_{p a}$ - energia pochłonięta przez jeden amortyzator gumowy.

Całkowita energia przejęta przez układ dwóch zderzaków i dwóch amortyzatorów gumowych

$$
\begin{aligned}
& E_{p s}=2 E_{p z s}+2 E_{p a}=2 \cdot 4125+2 \cdot 1500[\mathrm{~J}]=11250[\mathrm{~J}] \\
& E_{p d}=2 E_{p z d}+2 E_{p a}=2 \cdot 525+2 \cdot 1500[\mathrm{~J}]=4050[\mathrm{~J}]
\end{aligned}
$$
gdzie:

$E_{p s}$-energia pochtonięta przez układ wyznaczona na podstawie charakterystyki statycznej

$E_{p d}$-energia pochtonięta wyznaczona na podstawie charakterystyki dynamicznej

Z zasady zachowania energii mechanicznej energia kinetyczna ciagnika przed najazdem jest równa energii pochłoniętej przez elementy podatne, stad prędkość najazdu wynosi:

$$
\begin{aligned}
& V_{s}=\sqrt{\frac{2 \cdot E_{p s}}{m}}=\sqrt{\frac{2 \cdot 11250}{10000}}\left[\sqrt{\frac{J}{\mathrm{~kg}}}\right]=1,5\left[\frac{\mathrm{m}}{\mathrm{s}}\right]=5,4\left[\frac{\mathrm{km}}{\mathrm{h}}\right] \\
& V_{d}=\sqrt{\frac{2 \cdot E_{p d}}{\mathrm{~m}}}=\sqrt{\frac{2 \cdot 4050}{10000}}\left[\sqrt{\left.\frac{\mathrm{J}}{\mathrm{kg}}\right]}\right]=0,9\left[\frac{\mathrm{m}}{\mathrm{s}}\right]=3,2\left[\frac{\mathrm{km}}{\mathrm{h}}\right]
\end{aligned}
$$

gdzie:

$V_{s}$-prędkość nabiegania ciagnika wyznaczona na podstawie charakterystyki statycznej

$V_{d^{-}}$prędkość nabiegania ciagnika wyznaczona na podstawie charakterystyki dynamicznej 
Based on the rules regarding conservation of mechanical energy, the kinetic energy of the tractor before contact for the run-in is equal to the energy absorbed by the flexible buffer elements, hence the run-in speed can be determined:

$$
\begin{aligned}
& V_{s}=\sqrt{\frac{2 \cdot E_{p s}}{m}}=\sqrt{\frac{2 \cdot 11250}{10000}}\left[\sqrt{\frac{J}{\mathrm{~kg}}}\right]=1,5\left[\frac{\mathrm{m}}{\mathrm{s}}\right]=5,4\left[\frac{\mathrm{km}}{\mathrm{h}}\right] \\
& V_{d}=\sqrt{\frac{2 \cdot E_{p d}}{\mathrm{~m}}}=\sqrt{\frac{2 \cdot 4050}{10000}}\left[\sqrt{\frac{\mathrm{J}}{\mathrm{kg}}}\right]=0,9\left[\frac{\mathrm{m}}{\mathrm{s}}\right]=3,2\left[\frac{\mathrm{km}}{\mathrm{h}}\right]
\end{aligned}
$$

where:

$V_{s} \quad$ - tractor run-in speed determined based on static characteristics

$V_{d} \quad$ - tractor run-in speed determined based on

dynamic characteristics

The dynamic characteristics presented in Fig. 10.1 were determined for the initial run-in speed of $12 \mathrm{~m} / \mathrm{s}$, the speeds obtained from the calculations were much lower, however. Hence, it can be concluded that the speed of the tractor slamming onto a stationary wagon equipped with a category $\mathrm{C}$ bumper, at which a compressive force of $300 \mathrm{kN}$ is reached, was about $4 \div 5$ $[\mathrm{km} / \mathrm{h}]$.

\section{Conclusions \\ Vehicle frame structure}

The main load-bearing element is the box frame Fig. 8.1 , attached to the tractor's rear axle. As in the case of the front buffer system, the load-bearing structure of the rear buffer system was subjected to simulations of compression, lifting and tensile tests. The maximum stress of $354 \mathrm{MPa}$ was recorded during the compression test of the load-bearing structure Fig. 8.4 in the corners of the openings of the upper plate of the frame, which exceed the permitted stress limit $\delta_{\text {dop }}=309$ MPa. Stress concentrations in these points were the result of too small radii of the curves in the rectangular slab cutouts. It was recommended to enlarge the radius of the bends, which significantly reduced the stress level to well below the permissible values.

When stretching the system, the maximum stress of $224 \mathrm{MPa}$ was recorded (Fig. 8.6), and for lifting - 252 MPa (Fig. 8.8), which was below the minimum permitted stress $\delta_{\text {dop }}=309 \mathrm{MPa}$.

\section{Buffer beam}

The maximum stress values were recorded for a compression test of $339 \mathrm{MPa}$ (Fig. 9.2) in the rear vertical flange of the buffer beam in the area of the beam's internal ribs within the region where the beam was attached. There were slight local exceedances of stress limit values, which should be considered permissible under extraordinary loads.

During the beam tensile test, the permissible stress limit value in the structure of the buffer beam was not exceeded.
Charakterystyka dynamiczna przedstawiona na rys. 10.1 została wyznaczona dla prędkości początkowej najazdu $12 \mathrm{~m} / \mathrm{s}$, uzyskane prędkości z obliczeń są znacznie mniejsze. Stąd można wnioskować, iż prędkość nabiegania ciagnika na nieruchomy wagon wyposażany w zderzak kategorii C przy której wystąpi siła ściskająca $300 \mathrm{kN}$ wynosi $4 \div 5[\mathrm{~km} / \mathrm{h}]$.

\section{Wnioski \\ Konstrukcja skrzynkowa}

Głównym elementem nośnym jest skrzynia rys. 8.1 zamocowana do tylnego mostu ciagnika. Podobnie jak w przypadku przedniego układu pociagowego strukturę nośną tylnego układu poddano symulacyjnym próbom ściskania, podnoszenia i rozciagania. Maksymalne naprężenia o wartości $354 \mathrm{MPa}$ zarejestrowano przy próbie ściskania skrzyni rys. $8.4 \mathrm{w}$ narożnikach otworów górnej płyty skrzyni, które przekraczają naprężenia dopuszczalne $\delta_{\mathrm{dop}}=309 \mathrm{MPa}$. Spiętrzenia naprężeń w tych miejscach są wynikiem zbyt małych promieni łuków w prostokątnych wycięciach płyty. Zalecono powiększyć promienie łuków, co zdecydowanie wpłynęło na obniżenie poziomu naprężeń poniżej wartości dopuszczalnych.

Przy rozciaganiu układu zarejestrowano maksymalne naprężenia o wartości $224 \mathrm{MPa}$ (rys. 8.6), a przy podnoszeniu $252 \mathrm{MPa}$ (rys. 8.8), co mieści się poniżej naprężeń dopuszczalnych $\delta_{\text {dop }}=309 \mathrm{MPa}$.

\section{Belka zderzakowa}

Maksymalne naprężenia zarejestrowano przy próbie ściskania $339 \mathrm{MPa}$ (rys. 9.2) w tylnym pionowym pasie belki w okolicy żeber wewnętrznych belki w obrębie mocowania belki. Wystapiły niewielkie lokalne przekroczenia naprężeń, co przy obciążeniach nadzwyczajnych należy uznać za dopuszczalne.

Przy próbie rozciagania belki nie stwierdzono przekroczenia naprężeń dopuszczalnych w konstrukcji belki zderzakowej.

\section{Hak pociągowy}

Analiza została przeprowadzona dla zakresu liniowosprężystego. Przekroczenia granicy plastyczności wynikają z naprężeń powierzchniowych (kontaktowych) i nie wpływają na bezpieczną eksploatacje konstrukcji. $\mathrm{W}$ pozostałych przekrojach nie zarejestrowano przekroczeń naprężeń dopuszczalnych

\section{Podsumowanie}

Ocenę wytrzymałości ustrojów nośnych ciągnika wykonano w oparciu o badania symulacyjne zespołów składowych fabrycznej struktury nośnej ciagnika oraz zespołów dodatkowych zaprojektowanych i wytworzonych w Sieci Badawczej Łukasiewicz - IPS „TABOR”, stanowiących konstrukcję urządzeń pociągowo-zderznych.

Do badań symulacyjnych wykorzystano oprogramowanie ABAQUS 6.12-2. Do oceny wytrzymałości 


\section{Drawbar}

The analysis was performed for the linear-elastic range. The values exceeding the yield point resulted from surface (contact) stress and do not affect the safe operation of the structure. In the remaining crosssections, the permissible stress values were not exceeded.

\section{Summary}

The strength of the tractor load-bearing structures was assessed with the use of simulation tests of the components of the factory tractor model load-bearing structure, as well as for additional models designed and manufactured in the Łukasiewicz Research Network IPS "TABOR", constituting the structure of the pullbuffer systems.

The ABAQUS 6.12-2 software was used for the simulation tests. The fulfillment of the strength criteria for the compressive forces of $300 \mathrm{kN}$ and tensile forces of $150 \mathrm{kN}$ acting on the elements of the pull-buffer system was used in order to assess the strength of the tractor supporting structure in the context of its suitability for adaptation to a rail-road tractor.

Railway regulations outlining the rules of shunting traffic (Instruction on shunting technique Ir-9R34) allow the locomotive to run-in into the attached wagons at a maximum speed of $3 \mathrm{~km} / \mathrm{h}$.

The results of the analysis carried out in point 5 of this article, for a road-rail tractor with a mass of $\sim 10$ tons, has shown that the assumed compressive force of the supporting structure of the pull-buffer systems (300 $\mathrm{kN}$ ) was achieved at the tractor run-in speed with the wagons of $4-5 \mathrm{~km} / \mathrm{h}$, which was higher than permitted by the regulations.

The maximum tractive force (tensile) obtained in traction tests during the start-up of the tractor-wagons set was $\sim 55 \mathrm{kN}$.

Assuming the tensile force on the buffer system of 150 $\mathrm{kN}$ for the simulation tests, ensured an approximately three-fold safety margin for the point of breaking the shunting trainset composition. zespołów nośnych ciagnika w kontekście jego przydatności do adaptacji na ciagnik szynowo-drogowy przyjęto spełnienie kryteriów wytrzymałości dla sił ściskających $300 \mathrm{kN}$ oraz rozciagających $150 \mathrm{kN}$ działających na zespoły układu pociagowo-zderznego.

Przepisy kolejowe regulujące zasady prowadzenia ruchu manewrowego (Instrukcja o technice pracy manewrowej Ir-9R34) dopuszczają dojazd lokomotywy do doczepionych wagonów z prędkością maksymalną $3 \mathrm{~km} / \mathrm{h}$.

Jak wykazała analiza przeprowadzona w punkcie 11 niniejszego artykułu przy ciagniku szynowodrogowym o masie $\sim 10$ ton założoną siłę ściskającą konstrukcję nośną urządzeń pociągowo-zderznych $(300 \mathrm{kN})$ osiagnięto przy prędkości nabiegania ciągnika na wagony 4-5 km/h większej od dozwolonej przepisami.

Maksymalna siła pociągowa (rozciągająca) uzyskana w badaniach trakcyjnych przy rozruchu składu ciagnik - wagony wyniosła $\sim 55 \mathrm{kN}$.

Przyjmując $\mathrm{w}$ badaniach symulacyjnych siłę rozciągającą układ pociagowo-zderzny o wartości $150 \mathrm{kN}$ zagwarantowano w przybliżeniu trzykrotny zapas bezpieczeństwa na zerwanie składu pociagu manewrowego.

\section{Bbliography / Bibliografia}

[1] PN-EN 10025 Wyroby walcowane na gorqco niestopowych stali konstrukcyjnych. Warunki techniczne dostawy.

[2] PN-EN 15551 Kolejnictwo. Zderzaki.

[3] Medwid M., Daszkiewicz P., Czerwiński J., Jakuszko W. - Sieć Badawcza Łukasiewicz-Instytut Pojazdów Szynowych „Tabor”, Kazimierczak E.- CLAAS Polska: Ciagnik szynowo-drogowy $z$ napędem spalinowoelektrycznym. Pojazdy Szynowe, 2019, nr 3.

[4] Medwid M., Jakuszko W., Kazimierczak E.: Cechy konstrukcyjne ciagnika bazowego wybranego do adaptacji na pojazd szynowo-drogowy nowej generacji. Pojazdy Szynowe, 2017, $n r 3$.

[5] Medwid M., Stawecki W., Czerwiński J., Jakuszko W., Kazimierczak E.: Modelowanie struktury manewrowego ciagnika szynowo-drogowego CLAAS ARION 620. Pojazdy Szynowe, 2017, nr 2.

[6] Bryk K., Łukaszewski K., Medwid M.: Symulacyjne badania bezpieczeństwa ruchu ciagnika szynowodrogowego CLAAS ARION 620. Międzynarodowa Konferencja Naukowa TRANSPORT XXI WIEKU. Artamów, 30.08. $\div 02.09 .2016$.

[7] Medwid M.: Hybrydowe pojazdy kolejowo-drogowe zaprojektowane $i$ wytwarzane $w$ Polsce. Technika Transportu Szynowego, 2005, nr 7-8.

[8] Medwid M., Stawecki W., Czerwiński J., Jakuszko W.: Wielozadaniowy ciagnik szynowo-drogowy nowej generacji. Pojazdy Szynowe, 2016, nr 3. 